\title{
An Archaic Jewish-Christian Liturgical Calendar in Abba Giyorgis of Sägla
}

\author{
Basil Lourié \\ National Research University Higher School of Economics (HSE), St. Petersburg \\ University of Aerospace Instrumentation, St. Petersburg, Russia \\ hieromonk@gmail.com
}

\begin{abstract}
Two difficult passages are analysed in the 26th homily of the book Mäṣhafä Mośțir by Abba Giyorgis of Sägla, which are dealing with transition from the Old Testament Jewish calendar to the Christian calendar with its veneration of Sunday. The Jewish calendar Abba Giyorgis kept in mind was similar to those of 1 Enoch or Jubilees. According to his understanding, the Christian Sunday was already implied in the Mosaic Law as the year of release, as he has demonstrated with calendrical caluculations.
\end{abstract}

\section{Keywords}

Ethiopian Church - Abba Giyorgis of Sägla - Mäṣhafä Məśțir - liturgical calendars Jewish Second Temple period calendars - 364-day calendars - Julianism

\section{Introduction}

The Sunday in Albis or, as it is called in the Byzantine tradition, the Sunday of Antipascha or Thomas Sunday, is the day when the Church preachers throughout the world recall the institution of the weekly commemoration of the resurrection of Christ on Sunday. Abba Giyorgis of Sägla ${ }^{1}$ near 1424 was not an exception, save that he was preaching on the eve of this Sunday, on Saturday

1 Died $c a 1425 / 26$ at the age of 6o. On his personality and works, s. G. Colin, "Giyorgis of Sägla," in: $E A E$, vol. 2, p. 812, and, especially, A. Bausi, "Məśțir: Mäșḥafä məśțir," $E A E$, vol. 3, pp. 941-944. 
- as it was required by his doctrine of the perpetuated veneration of both Saturday and Sunday in Christianity within the 49-hour Sabbath. ${ }^{2}$ His homily, be-

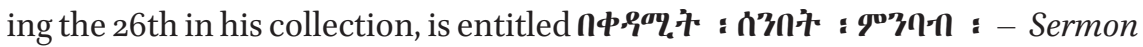
on the First Sabbath, that is, on the first Sunday after the Easter. ${ }^{3}$

He became an exception in another respect, however. He had a difficult task: to justify the Sunday veneration from the Old Testament. Indeed, this veneration was established, according to him, by Christ himself, but this was not a sufficient explanation. If something is truly established by Christ, it could have not been possible in other way than a development or, rather, "fulfilment" of some part of the Mosaic Law. Thus, for being established by Christ, the Sunday veneration would have been implied by Moses. ${ }^{4}$ And, indeed, according to Abba Giyorgis, Sunday was hidden already in the Mosaic Law. This is the point of the passage that we have now to restore and to read.

Yaqob Beyene in his critical edition (1993) has already collected the readings of different manuscripts, which show, most of all, that Ethiopian scribes were not always especially acquainted with Abba Giyorgis' calendrical ideas. Yaqob Beyene himself proposed a reconstruction of the original text and a translation, but, without any clear understanding of contents, both of them are not always satisfactory. After him, somewhat another reconstruction of the text and an interpretation has been proposed by me in $1999 ;^{5}$ the interpretation as a whole, I must confess, was erroneous, whereas the reconstruction was more helpful. Moreover, August Dillmann in his Lexicon linguae aethiopicae $(1865)^{6}$ partially studied the passage in question according to one manuscript available to him but lost now, providing a series of pertinent observations and an

2 S., for the details, Getatchew Haile, "The Forty-Nine Hour Sabbath of the Ethiopian Church," Journal of Semitic Studies, 23 (1988), pp. 233-254.

3 Giyorgis di Saglā, Il Libro del Mistero (Mașhafa Mesțir). Ed. Yaqob Beyene, I-II (CSCO, 515-516, 532-533; Aeth, 89-90, 97-98), Louvain, 1990-1993, here vols. 532-533, pp. 100-175/61-99 (txt/ tr.); thereafter the references to the text and/or the translation only by the page number.

4 Getatchew Haile mentions an unpublished anonymous homily entitled Darsan bä’antä sänbätat ("Treatise on the Sabbaths") "...against those Christians who refused to observe Sunday like Saturday, on biblical grounds!"; Getatchew Haile, "A Study of the Issues Raised in Two Homilies of Emperor Zär'a Ya‘eqob of Ethiopia," Zeitschrift der Deutschen Morgenländischen Gesellschaft, 131 (1981), pp. 85-113, here 104-105, quoted p. 104.

5 В. М. Лурье, “Авва Георгий из Саглы и история юлианизма в Эфиопии” [B. Lourié, “Abba George from Sägla and the History of Julianism in Ethiopia"], Христианский Восток [Christian Orient], 1 (7) (1999), pp. 317-358, esp. pp. 334-346.

6 A. Dillmann, Lexicon linguae aethiopicae cum indice latino, Leipzig, 1865 (reprinted many times); thereafter $L L A$, with a reference to the column number. 
explanation of the general meaning, which I consider now to be right, whereas I disagreed with Dillmann in my 1999 analysis.

In the present study, I provide some corrections to Yaqob Beyene's edition of the relevant passage and especially to his translation. My present understanding of the passage will follow Dillmann's line of reasoning, which could be confirmed with a number of data not taken into account by Dillmann yet.

The ultimate goal of our reconstruction is the image of the Old Testament Jewish calendar Abba Giyorgis had in mind.

\section{Text and Translation}

Yaqob Beyene's edition is based on 13 manuscripts. Among them, there are two pairs of almost perfect twins. The text of the now lost Tübingen manuscript ${ }^{7}$ is partially preserved, for the fragment we will deal with, in two quotations by August Dillmann. Thus, the total number of manuscripts for the most difficult place in our passage is 14, but only 12 witnesses are, in some frames, independent of each other.

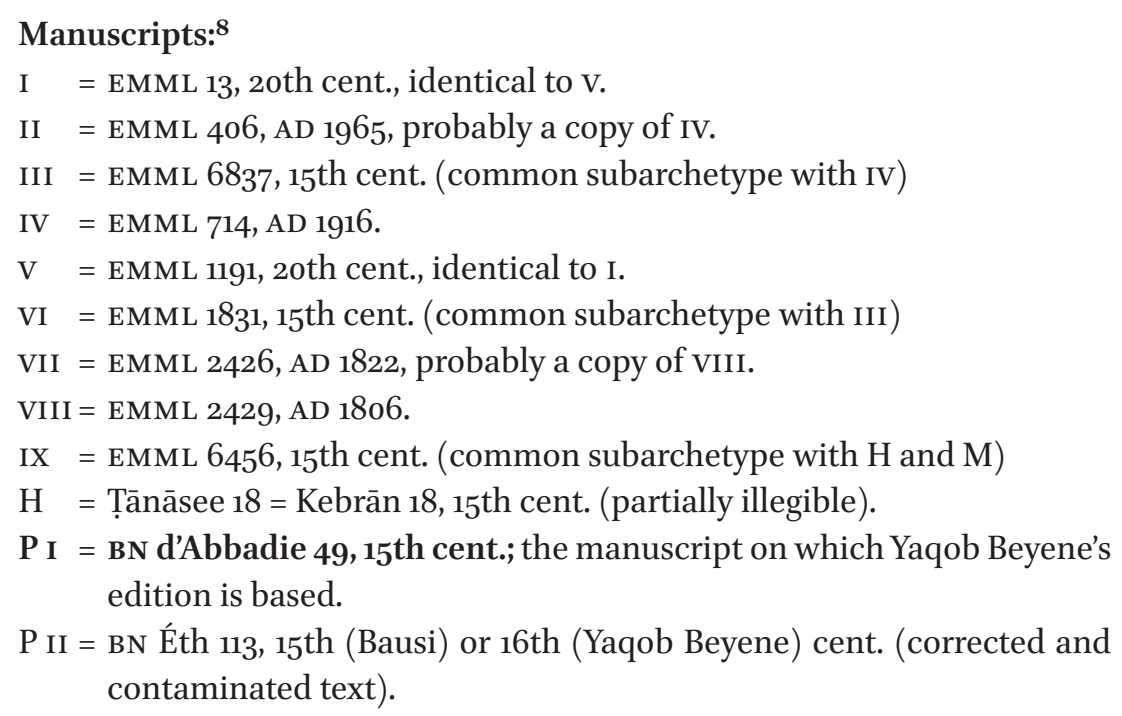

7 Described by Heinrich von Ewald, "Ueber die Aethiopischen Handschriften zu Tübingen," Zeitschrift für die Kunde des Morgenlandes, 5 (1844), pp. 164-201, here 194-196.

8 Cf., in addition to Yaqob Beyene’s description, Bausi, "Məśțir: Mäșḥafä məśțir," p. 943. 
M = Mäqälä, $15^{\text {th } \text { cent. }}$

T = Tübingen (Basel) ms (unknown date), now lost. ${ }^{9}$

Yaqob Beyene did not propose a stem of the manuscripts. His identification of the subarchetypes (mentioned above) is based on the common readings and not on the common errors, not to say on some kind of statistical cluster analysis. Therefore, it is to be taken as tentative. His edition follows the unique manuscript P I which he considers to be the best one, with addition of the variants mostly from the manuscripts other than H, II, V, and VII.

The text below declines from Beyene's edition (pp. 170-171) where I consider the readings of $\mathrm{P} I$ to be secondary. These cases are marked with red.

Text:

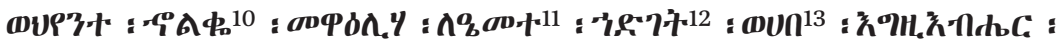

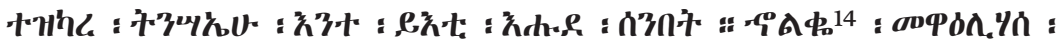

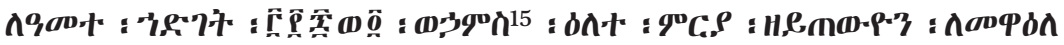

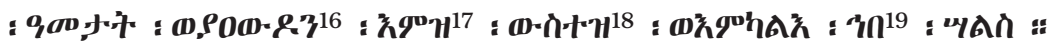

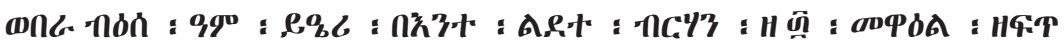

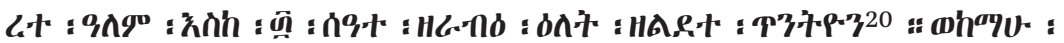

9 Quoted apud Dillmann, LLA, col. 169.

10 I, IV "TA中:

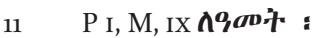

12 M om "I.

13 M HWUn : "which (the Lord) gave..."; the sense is hopelessly lost: the Lord gave the commemoration of his resurrection instead of the regular year.

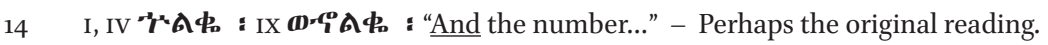

15 VI

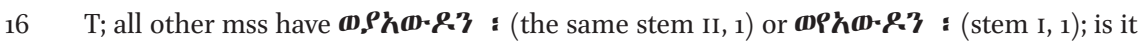
possible that Dillmann corrected the original spelling of T?

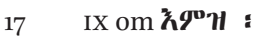

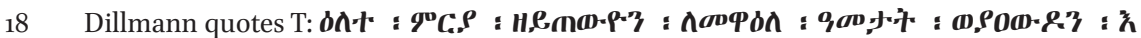
耳ำ : $\boldsymbol{0} \cdot \boldsymbol{\lambda}+\boldsymbol{H} \boldsymbol{1}$ : and explains "qui efficit, ut singulis annis dies a loco, quem inter hebdomadis ferias obtinent, moveantur et in feriam sequentem proptudantur" (LLA, col. 169).

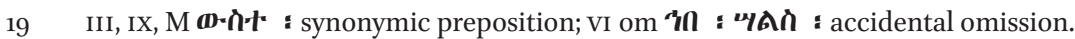

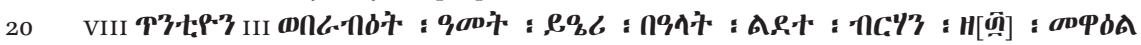

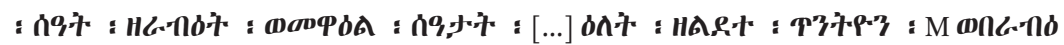

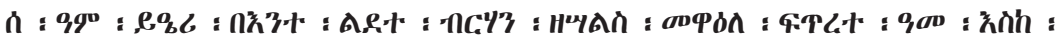

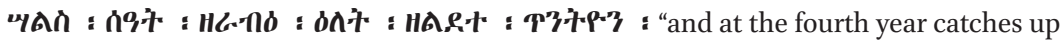
- due to the birth of the light (occurring) after three days (after) creation of the year [sic!

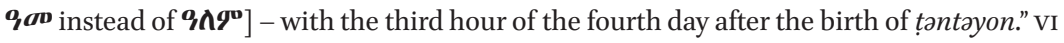




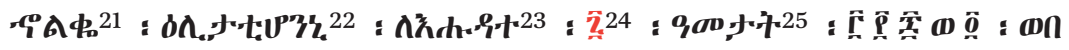

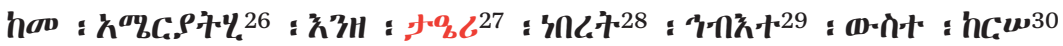

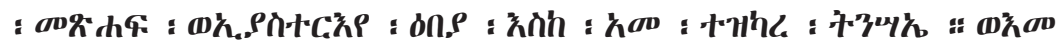

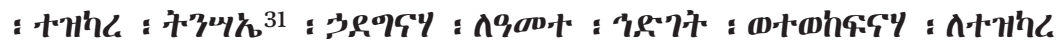

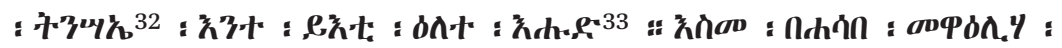

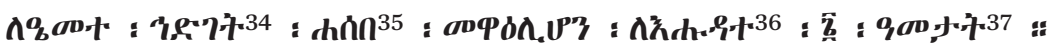

Translation:

And in substitution of the number of the days of the year of release the Lord gave the commemoration of His resurrection, that is the first ${ }^{38}$ of

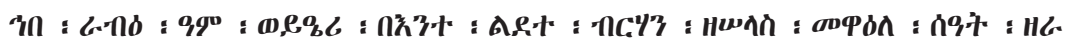

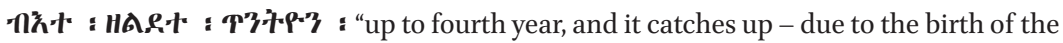
light (occurring) after thirty days, (at) the fourth hour, after the birth of tantayon." IX $\boldsymbol{\text { on }}$.

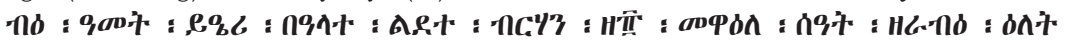
: HAS. : TPTP. : "and at the fourth day catches up with the day of the birth of the light (occurring) after 80 days, (at) the fourth hour (at) the day of the birth of tantayon" (this reading would imply that Sunday occurs on Wednesday!).

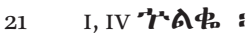

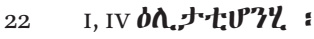

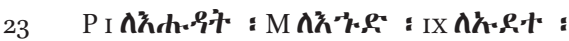

$24 \mathrm{M} \mathbf{\boldsymbol { Z }}$ (apparently a typo in the apparatus, n. 2090:

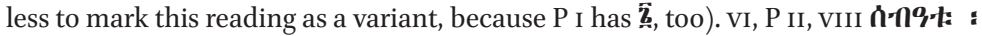
III 9on't :

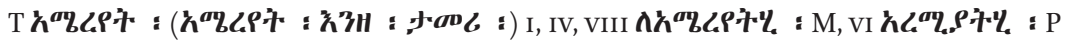

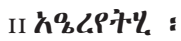

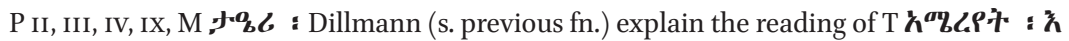

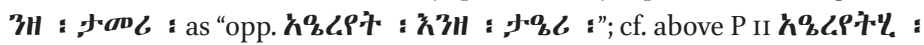

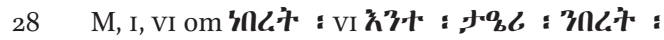

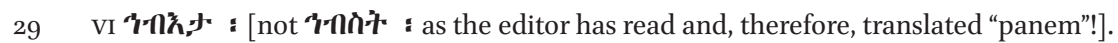

30 III, IX Čñn : "head."

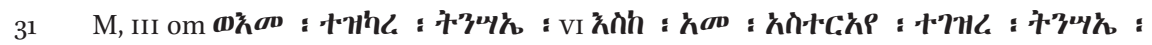

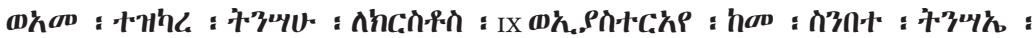

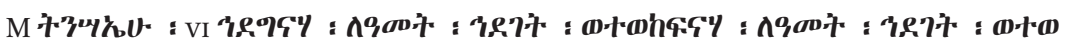

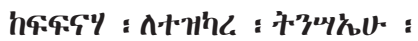

33 P II heves:

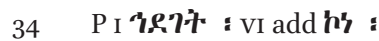

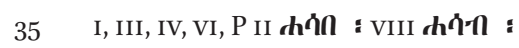

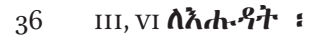

37 М

38 Lit. "one," as in the Greek prototype of the phrase; here and below I will translate "first" instead of "one/ones." 
the Sabbath [= $\left.\mu^{\prime} \alpha \tau \hat{\omega} \nu \sigma \alpha \beta \beta \dot{\alpha} \tau \omega \nu\right]$. And ${ }^{39}$ the number of the days of the year of release is 364 . And the fifth one is the shifting day that rolls around the days of the years and revolves them, from this to that, and from the second to the third, and, at the fourth year, catches up [lit. becomes equal] - due to the birth of the light after 30 days after the creation of the world - with the 3oth hour of the fourth day after the birth of the tantayon. And because the number of the first days [= Sundays] of the seven years is 364 , and because (the fifth day) shifted them when catching up [lit. becoming equal $]^{40}$, it $[s c$., the day of resurrection $=$ Sunday $]$ remained hidden in the bosom of the Scripture, and its greatness has not been revealed until the commemoration of the resurrection. And, for the commemoration of the resurrection, we have left the year of release and accepted the commemoration of the resurrection that is the first [of the Sabbath = Sunday], because with the reckoning of the days of the year of release he [sc. the Lord] reckoned the first [after the Sabbath] days [= Sundays] of the six years.

One note is to be provided immediately. Abbas Giyorgis often indicates Sunday with its name derived from its Jewish name in Greek $\mu i \alpha \tau \hat{\alpha} \nu \sigma \alpha \beta \beta \alpha \dot{\tau} \tau \omega \nu$, often reduced to the first word "one." Thus, some passages that became stumbling blocks for Yaqob Beyene (judging from his translation) $)^{41}$ are perfectly clear. Namely, the number of the Sundays in seven 364 -day years is exactly $52 \times 7=$ $364=$ the number of the days of the year of release. Therefore, the reading " 7 " in the corresponding place of the fragment above, preserved in a part of manu-

"And" only in ms IX.

40 Translated according to the mss. having $\mathbf{F} \mathbf{C}$ : and not $\boldsymbol{F} \boldsymbol{C}$ : "shifting."

41 Cf. his translation of the same passage (p. 96): "Ed è invece del numero dei giorni dell'anno della remissione che il Signore diede in memoria della sua resurrezione, che è el primo [giorno] del sabato. Ora, il numero di giorni dell'anno della remissione è di 364 [giorni], e un quinto è il giorno dello spostamento, [disparità] che sposta i giorni degli anni e li fa compiere il ciclo da questo a quello e dal secondo al terzo; al quarto anno, invece, per ragione della nascita della luce dei trenta giorni della creazione del mondo fino al'ora trentesima del giorno della nascita del tenteyon. Così anche il numero dei giorni dei primi [giorni] dei sei anni è di 364; è, come aveva spostato uguagliando, e come aveva uguagliato uguagliando [spostando], il pane stava nel ventre della Scrittura e non apparve la sua grandezza fino al momento della memoria della resurrezione. E, al momento della memoria della resurrezione, noi abbiamo abbandonato già l'anno della remissione e abbiamo accettato la memoria della resurrezione, che è il giorno del primo [giorno della settimana], perchè [il Signore] con il computo dei giorni della remissione ha calcolato i giorni dei primi [giorni della settimana] dei sei anni." 


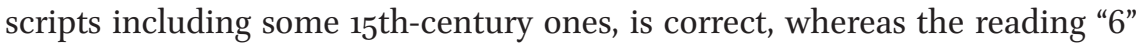
(of P I and some other manuscripts) is erroneous, due to the similarity of the two numbers in the Ethiopic script and, probably, influenced by the reading "six years" at the end of our fragment.

\section{Interpretation}

It is obvious that the fragment concerns, in some way, the 364-day calendar, whereas the actual calendar of Abba Giyorgis is already the 365 -day one. Abba Giyorgis' pre-Christian 364-day calendar contained the seven-year cycle with the year of release, which is replaced, for the Christians, with the weekly Sunday veneration. This replacement has been performed with introduction of the "fifth day," that is, the $365^{\text {th }}$ day of the year. This day caused the shift of the days of year in relation to the weekdays (in the 364-day calendar, all the days of the year have their fixed weekdays). It was Dillmann who understood the meaning of the term $\boldsymbol{\delta} \boldsymbol{n} \boldsymbol{+}$ : $\mathbf{9 P}^{\mathbf{P}} \boldsymbol{P}$ : as a derivate from the Semitic root with the meaning "permutavit, commutavit;" cf., in Wolf Leslau's etymological dictionary, "movable day" with the etymology from the Hebrew/Aramaic root mwr (Hiphil hemir "exchange"). ${ }^{42}$

Abba Giyorgis uses the astronomical term tantəyon which meaning is "the beginning of the calendar," being a transliteration of Greek $\tau \hat{\omega} \nu \theta \varepsilon \hat{\omega} \nu$. The meaning of the Greek term was the indication of the weekday of the planetary week where each day was consecrated to some god. The beginning of the calendar in Ethiopia (following to the majority of the Second Temple Jewish calendars) is Wednesday, the day when the luminaries were created, and so, tantəyon means Wednesday. ${ }^{43}$ Thus, the phrase "the birth of təntวyon" means Wednesday (probably, the first one in the year), and the fourth day from this weekday is Saturday.

The phrase "the birth of the light" means Sunday, the first day of creation. "The 3 oth day after the creation of the world" means the 3oth day of the first month (30.I). It falls on Sunday when the first day of the year (1.I) falls on

42 W. Leslau, Comparative Dictionary of Ge'ez (Classical Ethiopic), Wiesbaden, 1991, p. 362.

43 The history of the term has been established by Otto Neugebauer, "Təəontyon," Orientalia [Rome], 44 (1975), pp. 487-488 [reprinted in idem, Astronomy and History: Selected Essays, New York, 1983, pp. 521-522]; cf. also idem, Ethiopian Astronomy and Computus (Österreichische Akademie der Wissenschaften, Philol.-hist. Kl., Sitzungsberichte, 347; Veröffentlichungen der Kommission für Geschichte der Mathematik, Naturwissenschaften und Medizin, 22), Wien, 1979, passim. Cf., for additional bibliography, E. Sokolinskaia, “Ṭəntyon," in: $E A E$, vol. 4, pp. 919-920. 
Friday, as it takes place at the third year of the four-year cycle of the Julian calendar. The phrase "due to the birth of the light after 30 days after the creation of the world" indicates that, before shifting of two weekdays at the fourth year, the beginning of the year has already reached Friday. It remains unclear to me why Abba Giyorgis preferred to refer to the 3oth day of the month, whereas he had in his disposition a number of other reference points.

To sum up, Abba Giyorgis describes shifting of the beginning of the year in respect to the weekdays in the following way. At the first year of the four-year cycle, the beginning of the year falls on Wednesday. Then, at the second and the third years, it moves by one day forward, that is, from Wednesday to Thursday and from Thursday to Friday. The next, fourth year is the bissextile one. This year, the shift is not of one but of two weekdays. Thus, this day falls on Sunday. For Abba Giyorgis, however, there is no Sunday as a separate day but rather a part of the 49-hour Sabbath. Therefore, he continues counting of the hours of the Sabbath after the number 24. The 3oth hour of Sabbath "the fourth day after the birth of təntzyon") is Sunday midnight, the approximate time of Christ's resurrection.

According to the Homily on the 49-Hour Sabbath ascribed to the same Abba Giyorgis, this Sabbath starts on the last hour of Friday, that is, about 5 p.m. ${ }^{44}$ Therefore, 30 hours of Sabbath would mean 11 p.m. - strictly speaking; from the context, however, it seems to me more likely that the author had in mind the Sunday midnight.

Now we are in a position to interpret the fragment as a whole. Sunday is introduced instead of the year of release. More exactly, as a four-year cycle instead of the seven-year cycle, and within the 365 -day year instead of the 364 -day year. In the 364-day calendar, the number of Sundays within seven years is equal to the number of the days of the year of release, 364 . Now, all these Sundays of seven years of the 364 -day calendar are reconsidered as the 364 days of the abolished year of release. For this purpose, a new four-year cycle has been established. It has been created with the addition of the fifth day to the 364-day year (the 366th day of the bissextile year is not discussed explicitly, whereas it is clearly implied in the two-day shift at the fourth year). This additional day shifts the beginning of the year according to the weekdays in such a way that, at the end of the whole cycle, the fourth day, the year begins at the time when the Lord resurrected. Thus, the most important year of the new four-year cycle is its last day, similarly to the former seven-year cycle, where the most important year was its last year, the year of release. 
The days of the year of release, now redistributed among the ordinary Sundays of seven years, were, in fact, the Christian Sunday festivals hidden within the Mosaic Law. They were "developed" as such via introducing the 365 th day into the 364-day year.

Abba Giyorgis does not explain the following problem. Seven 365-day years (or rather six 365-day and one 366-day years) contain not 364 Sundays but 364 $+1=365$ Sundays. This Sunday is certainly not a day of the former year of release, because the latter contained only 364 days. Then, what is its origin?

Despite the lack of an explicit answer, we can infer that this day is no other than that 365 th day that was introduced, according to Abba Giyorgis, by the Lord himself. It seems that its proper place among the weekdays is revealed, at the fourth year of the new cycle, as Sunday. Abba Giyorgis does not state this explicitly, but such an idea seems to me the most fitting with his calendrical construction as a whole.

\section{The "Jewish" (Old Testament) Calendar through Abba Giyorgis' Optics}

The Christians, especially in Ethiopia, were always reserving for themselves the right to decide what is truly Jewish and what is not. Thus, in the calendrical matters, the actual Ethiopian Easter computus contains an elaborated scheme of a "Jewish" liturgical calendar. It is certainly going back to some Jewish Second Temple tradition but is at variance with all other Jewish calendrical traditions known so far. ${ }^{45}$ The tradition meant by Abba Giyorgis is somewhat more recognisable, because he refers to the 364 -day (per year) calendar in both explicit and implicit ways.

Thus, in the passage which meaning we have just recovered, Abba Giyorgis explicitly mentions the 364-day year. Even more revealing is his odd reference in another place of the same homily, where he dates the feast of the Unleavened Bread to the ten-day period from Nisan 14 to Nisan 24 (p. 166).

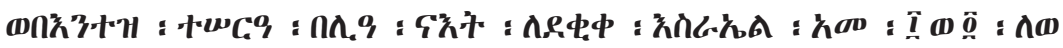

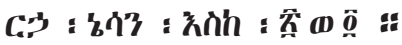

And because of this, it was established for the sons of Israel to eat the azyma (Unleavened Bread) from 14 of the month Nesan to 24 . vol. 1, pp. $784-787$. 
Needless to say that this is a blatant contradiction to the Torah (Lev 25:4-7; Deut 15:9-18 etc.). Nevertheless, it is perfectly understandable within known Jewish traditions. The addition of the day of the Passover, 14 Nisan, to the following multi-day feast of the Unleavened Bread (beginning on 15 Nisan) is not biblical but very ancient and quite widespread. The real problem is here the duration of the latter feast. According to the biblical and so far known extrabiblical data, its last day must be Nisan 21 and not 24 .

However, let us consider a - very common - fusion between the feasts of Passover and Unleavened Bread but now, inserted within a calendrical scheme similar to that of 1 Enoch and Jubilees. The Passover (14 Nisan) falls on Tuesday. The feast of Unleavened Bread begins on 15 Nisan, Wednesday, and ends on 21 Nisan (Tuesday of the next week). However, the calendar of Jubilees follows Leviticus' commandment to start the counting of the seven weeks of the Pentecost on Monday. Thus, this calendar starts its post-Passover period only on Monday 27 Nisan. The days between Nisan 21 and 27 exclusively are left without a clear liturgical purpose, even though they are a part of the most important festive period of the whole year.

There were different ways to avoid this inconvenience. For instance, there was a perfect scheme of 364-day calendar, where the first weekday of the calendar was Sunday and not Wednesday: this is the only Jewish calendar that allowed fulfilling all the requirements of Leviticus literally. ${ }^{46}$ Abba Giyorgis takes another option. He, instead, adds the ferial days occurring between 21 and 27 Nisan of the 364-day year that begins on Wednesday to the days of the feast of Unleavened Bread. These days are Nisan from 22 to 24, from Wednesday to Friday inclusively. In this way, the corresponding apparent distortion of Torah's commandment turns out to be an amendment.

We have to retain from this observation that the 364-day calendar meant by Abba Giyorgis was similar to those of the Book of Jubilees and $\imath$ Enoch, that is, presuming the beginning of the year on Wednesday. Indeed, these books are both present within the Ethiopian biblical canon.

46 On this calendar, s. B. Lourié, "Calendrical Elements in 2 Enoch," in: New Perspectives on 2 Enoch. No Longer Slavonic Only, ed. A. Orlov, G. Boccaccini, J. M. Zurawski (Studia Judaeoslavica, 4), Leiden - Boston, 2012, pp. 191-219; idem, "The Liturgical Calendar in the Joseph and Aseneth," in: Men and Women in the Early Christian Centuries, ed. W. Mayer, I. J. Elmer (Early Christian Studies, 18), Strathfield, 2014, pp. 111-134; idem, "The Liturgical Cycle in 3 Maccabees and the 2 Enoch Calendar," Revue biblique (forthcoming). 


\section{5}

\section{Conclusion}

Such a clear recollection of the 364 -day Jewish calendar is not common in Christian cultures. Even the "Nestorians" whose liturgical year is based on the 364-day year even now ${ }^{47}$ have no clear understanding that such was the Jewish year inherited by the Christians.

In the Ethiopian Church, even in the faction to which Abba Giyorgis belonged, the liturgical calendar was already based on the Julian one, in its Alexandrian guise. Thus, the knowledge of the early Jewish calendrical scheme had, in Abba Giyorgis, rather a theoretical than practical purpose.

This feature is not unique to Abba Giyorgis. The 364-day calendar became a major issue of the intra-monophysite polemics in the sixth century. Then, it was a distinctive trait of, at least, a part of the Julianist movement, the so-called Aaronites who left Syria and found a new home in Armenia. ${ }^{48}$

As I have shown in my 1999 paper, ${ }^{49}$ the theology of Abba Giyorgis belongs to the Julianist tradition, and, moreover, we know that the heirs of the Julianist in the fourteenth- and fifteenth-century Ethiopia were maintaining close connexions with their Armenian coreligionists. The calendrical background of Abba Giyorgis seems to be going back to the same Julianist background.

47 Cf. еsp. Софония [Соколовский; Sofonija <Sokolovskij>], Современный быт u литургия христиан инославных Иаковитов и Несториан... [Contemporary Customs and Liturgy of the Heterodox Christians Jacobites and Nestorians...], St Petersburg, 1876, pp. $270-275$, with the conclusion that the liturgical year according to the main liturgical book of the Assyrian Church, Hudra consists of $5^{2}$ or 53 weeks.

48 M. van Esbroeck, "Un court traité pseudo-basilien de mouvance aaronite conservé en arménien," Le Muséon, 100 (1987), pp. 385-395 [reprint in: idem, Aux origines de la Dormition de la Vierge. Études historiques sur les traditions orientales (Variorum Reprints. Collected Studies Series, CS, 380), Aldershot, 1995, ch. VIII].

Лурье, “Авва Георгий из Саглы”; cf. B. Lourié, “Julianism,” in: $E A E$, vol. 3, pp. 308-310. 